\title{
Pengaruh Ekstrakulikuler Coding pada Siswa Sekolah Dasar Guna Meningkatkan Computational Thingking di Sekolah Al-Azhar Syifa Budi Solo
}

\author{
Dafa Rizki Purna Ramadhan'1), Aulia Qisthi Rosyada ${ }^{2)}$, Widya Marliza ${ }^{3),}$ \\ Dinda Eya Putri Kasatri ${ }^{4}$, Irma Yuliana ${ }^{5)}$, \\ 1)2)34)5)Universitas Muhammadiyah Surakarta \\ 1)a710180097@student.ums.ac.id 2)a710180033@student.ums.ac.id \\ 3)a710180038@student.ums.ac.id ${ }^{4)}$ a710180098@student.ums.ac.id \\ 5)Irma.yuliana@ums.ac.id \\ doi: 10.23917/blbs.v2i1.11616
}

\begin{abstract}
Abstrak. Sebagian besar dari kita tidak tahu mengenai apa yang membuat smartphone, laptop, social media, dan video game kita dapat berjalan. Pengetahuan pemrograman dasar atau coding dapat mengubah cara kita berinteraksi dengan teknologi yang kita gunakan setiap hari, dan dapat membuka mata kita pada kemungkinan pengkodingan yang tak terbatas. Setelah melakukan observasi di Sekolah Dasar Al-Azhar Syifa Budi Solo, sekolah memberikan pembelajaran Coding kepada para siswa yang merupakan tanggapan dari kemajuan teknologi informasi di masa kini, melihat dari para siswa yang telah mengenal gadget, games, bahkan apps, sekolah merasa perlu adanya penyaluran ketertarikan para siswa terhadap kemajuan teknologi dengan memberikan pembelajaran Coding for Kids. Dengan adanya program pembelajaran Coding ini anak akan memiliki kemampuan computational thinking, Complex Problem Solving, Limitless Imagination dan Creativity. Dengan kemampuan computational ini anak dapat mengkomunikasikan pikiran dengan cara logika dan terstruktur, seperti instruksi yang diberikan ke komputer, sehingga nantinya dapat digunakan untuk memecahkan masalah dengan bantuan teknologi yang didasari oleh computer.
\end{abstract}

Kata Kunci:, anak sekolah dasar, computational thinking. pembelajaran coding

\section{PENDAHULUAN}

Program Pengenalan Lapangan Persekolahan I (PLP I) merupakan tahapan pertama dalam pengenalan lapangan persekolahan yang wajib dilaksanakan oleh mahasiswa FKIP dan FAI UMS untuk memenuhi tugas mata kuliah Magang Observasi Persekolahan. Dalam kegiatan ini mahasiswa hanya melakukan observasi yang mencakup struktur organisasi dan tata kerja di sekolah, kultur sekolah, dan pelibatan aktivitas pendidikan di sekolah. Melalui kegiatan ini mahasiswa diharapkan mampu membentuk empat kompetensi yang dipersyaratkan bagi calon guru profesional, yaitu: kompetensi kepribadian, kopetensi sosial, kompetensi pedagogik, dan kompetensi profesional. 
Kegiatan Pengenalan Lapangan Persekolahan I (PLP I) dilaksanakan secara terstruktur dan merupakanbeban belajar yang di tempuh pada semester genap dengan beban belajar tiap semester sekurang-kurangnya 1 SKS. Kegiatan PLP I akan dilanjutkan kegiatan PLP II untuk memantapkan kompetensi akademik kependidikan dan bidang studi melalui berbagai bentuk aktivitas di sekolah.

Sebagian besar dari kita tidak tahu mengenai apa yang membuat smartphone, laptop, social media, dan video game kita dapat berjalan. Pengetahuan pemrograman dasar atau coding dapat mengubah cara kita berinteraksi dengan teknologi yang kita gunakan setiap hari, dan dapat membuka mata kita pada kemungkinan pengkodingan yang tak terbatas.

Coding secara umum adalah menulis sekumpulan kode sesuai dengan aturan penulisan (syntax) tertentu dari bahasa pemrograman yang digunakan, seperti ; Java, Python, $C / C++$, dll. Dengan itu semua kita dapat memberikan daftar instruksi pada perangkat komputer sesuai dengan tujuan kita. Jadi coding adalah suatu teknik untuk menerjemahkan logika kedalam Bahasa pemrograman komputer melalui suatu aplikasi khusus seperti; Codeblocks, Visual Studio Code, Sublime Text, Scratch, dll.

Pembelajaran coding di sekolah dasar Al-Azhar Syifa Budi Solo dimulai pada tahun 2018 sebagai terobosan baru agar lebih maju dari sekolah lain termasuk sekolah Al-Azhar yang berada di Jakarta. Untuk mempersiapkan anak dalam menghadapi era modern dimana kemajuan teknologi sudah sangat pesat. Sebelumnya pembelajaran ini dinamakan computer science yang bertujuan untuk mengembangkan kemampuan berfikir logika anak pada siswa, sehingga menuntut anak agar memiliki penguasaan terhadap ilmu komputer.

Pembelajaran coding ini bukan menjadi mata pelajaran wajib yang harus ditempuh siswa-siswinya melainkan hanya sebagai ekstrakulikuler pilihan saja. Al-Azhar bekerjasama dengan yayasan DigiKids untuk membantu sekolah dalam mewujudkan pembelajarn coding kepada siswa, dengan menggunakan aplikasi yang telah disediakan DigiKids, yaitu aplikasi Scratch dimana aplikasi ini merupakan aplikasi yang dikhususkan untuk anakanak yang memiliki tingkat pemahaman dasar.

Aplikasi Scratch merupakan aplikasi pemrograman coding drag and drop, aplikasi ini memiliki sekumpulan perintah sederhana yang dapat dipahami oleh komputer, dengan aplikasi Scratch para siswa yang megikuti pembelajaran ektrakulikuler bisa menciptakan cerita, game hingga animasi sederhana.

Adapun rumusan masalah dalam artikel kami yaitu (a) Bagaimana peran dan pentingnya pembelajaran coding untuk 
siswa sekolah dasar? (b) Bagaimana dampak jika pembelajaran coding diterapkan dalam pembelajaran di tingkat sekolah dasar? Dengan demikian penelitian ini bertujuan untuk menganalisi pengaruh coding terhadap perkembangan daya pikir anak dengan adanya program ekstakulikuler coding di SD Al-Azhar Syifa Budi Solo. Manfaat yang diharapkan dari penelitian ini adalah hasilnya dapat dijadikan sebagai suatu referensi atau sumber informasi dalam pengaruh era modern melalui kelas ekstrakulikuler Coding ini.

\section{METODE PENELITIAN}

Adapun tempat penelitian ini dilaksanakan di ruang Laboratorium BahasaSD Al Azhar Syifa Budi Solo yang terletak di Jl. Haryo Panular No. 64, Panularan, Laweyan, Surakarta. Waktu penelitian ini dilaksanakan pada semester genap Tahun Pelajaran 2019/2020. Rincian kegiatan meliputi persiapan- persiapan pelaksanaan dan penyusunan laporan dilakukan selama 10 hari. Subjek penelitian ini adalah peserta didik SD AL Azhar Syifa Budi Solo yang megikuti kegiatan ekstrakulikuler coding. Disini peserta didik berperan sebagai penerima tindakan. Jumlah anak yang diteliti 6 anak terdiri dari 4 anak laki-laki dan 2 anak perempuan. Alat yang di gunakan pada penelitian ini sebagai berikut (a) Sperangkat Komputer, (b) Projector. Adapun bahan yang digunakan pada penelitian ini yaitu Aplikasi Scratch.

Pada penelitian ini menggunakan aplikasi Scratch, data diperoleh dengan melalui tindakan atau proses anak dalam menyelesaikan suatu permasalahan yang terjadi ketika melakukan coding, dimana anak akan memilih opsi atau pilihan yang benar dan sesuai dengan permasalahan yang dihadapi agar suatu permasalahan tersebut dapat berjalan dan teratasi. Sedangkan prosedur penelitian dilakukan peneliti dalam melihat perkembangan daya berfikir, kekreativitas, dan imajinasi anak melalui aplikasi Scratch adalah dengan menggunakan Metode Penelitian Dasar (Basic Research). Data yang dipilih dalam penelitian ini adalah data kuantitatif dan data kualitatif. Data kuantitatif berupa data tentang kemampuan berfikir peserta didik yang diperoleh dari sumber data primer yaitu peserta didik. Sedangkan data kualitatif berupa data tentang penerapan aplikasi Scratch dan data ini diperoleh dari sumber data primer yaitu pembimbing ektrakulikuler dan guru.Data dikumpulkan dengan menggunakan teknik-teknik sebagai berikut (a) Observasi, (b) Wawancara. Instrumen merupakan alat bantu yang digunakan untuk mencatat atau mendapatkan data yang diperlukan. 
Pembuatan instrumen disusun sebelum peneliti terjun ke lapangan. Dalam penelitian ini instrumen yang digunakan yaitu pedoman observasi dan pedoman wawancara. Pada penelitian yang menjadi pedoman observasi adalah anak yang mengikuti pembelajaran, aplikasi Scratch, dan cara anak dalam menyelesaikan permasalahan. Sedangkan yang menjadi pedoman wawancara adalah guru atau pembimbing yang memberikan instruksi dalam pemecahan masalah.

Data kemampuan tingkat berfikir dan imajinasi anak melalui aplikasi Scratch dianalisis dengan analisis komparatif data, yaitu membandingkan anak dengan indikator anak yang mengikti kegiatan ektrakulikuler dan yang tidak mengikuti ektrakulikuler.

\section{HASIL PENELITIAN DAN PEMBAHASAN}

Dari hasil penelitian yang telah dilakukan, penulis mendapati hasil bahwa pembelajaran coding dapat membentuk dan mengembangkan suatu pemikiran komputasional berupa pemikiran logika, imajinasi, dan kreativitas anak. Hal ini dibuktikan dari tingkat kesulitaan bertahap yang diberikan kepada anak, pertama anak diberi pemahaman terlebih dahulu bagaimana cara kerja dan fungsi dari perangkat komputer yang tersedia, setelah anak memahami perangkat komputer anak akan dipandu guru pembimbing ekstrakulikuler oleh yayasan DigiKids untuk mempelajari dasar-dasar dari aplikasi Scratch.

Anak kemudian diberikan informasi dari setiap perintah pemrograman yang tersedia, anak akan diberikan panduan awal yang sangat sederhana, dimulai dari menginput karakter, gambar latar belakang hingga sistematis cara aplikasi berjalan, dari hal tersebutlah anak mulai berfikir secara logika, anak mulai memahami suatu dampak dari hasil yang telah dilakukan oleh anak saat memasukkan perintah didalam aplikasi. Kemudian dari pemikiran logika tersebut anak mulai berimajinasi mengenai kejadian- kejadian yang dibayangkan oleh anak, dari pemerosesan pemikiran logika dan imajinasi anak menciptakan suatu karya, dimana karya tersebut merupakan hasil dari kreativitas anak.

Seperti yang sudah disebutkan sebelumnya, kemampuan pemikiran komputasional terletak pada proses yang dijalani, anak memasuki beberapa tahapan sebelum dapat melakukannya secara mandiri. Tahapan-tahapan tersebut sangat fundamental atau penting bagi proses pembelajaran anak sehingga tidak membuat anak menjadi bosan dan kehilangan ketertarikan terhadap coding Anak dalam melakukan percobaanya terkadang memilih untuk berkelompok ketika menghadapi suatu masalah. Anak dalam suatu kelompok dalam memecahkan masalah mungkin lebih dapat 
meningkatnya kemampuan mereka untuk menghasilkan ide-ide kreatif dibandingkan dengan kelompok normatif karena pemrograman Scratch memfasilitasi pemikiran yang berbeda dalam konteks figural.

Dari hasil wawancara yang dilakukan didapati beberapa hal sebagai berikut :

\section{A. Complex Problem Solving}

Penulis mendapati bahwa coding adalah bagian dari proses penyelesaian masalah. Untuk menyelesaikan masalah ini, anak membutuhkan pola berpikir yang komprehensif dengan dapat mempertimbangkan berbagai macam aspek yang saling berinteraksi dalam proses permasalahan tertentu (complex problem solving). Langkah- langkah penyelesaian masalah yang diberikan adalah dengan mendesain solusi berbasis komputasi (design thinking). Peserta didik yang paham terhadap coding memiliki konsep design thinking dan complex problem solving dibandingkan dengan peserta didik yang belum memeliki pemahaman coding.

\section{B. Computational Thinking}

Setelah anak mengerti bagaimana mendesain masalah dan memecahkan permasalahan yang kompleks, anak akan memiliki pemikiran yang lebih maju, tingkat pemikiran ini dikenal sebagai Computational Thinking (CT) atau pemikiran komputasional. CT adalah sebuah ilmu yang mempelajari bagaimana mendesain solusi dengan mempertimbangkan cara kerja komputer. Contoh materi CT paling sederhana adalah memahami bagaimana mendesain sebuah program komputer dengan diagram alir (flowchart). Contoh materi CT yang lain adalah memahami bagaimana komputer bekerja dengan logika komputasi (logic in computing). Materi CT lain yang cukup penting adalah memahami kompleksitas algoritme. Jika sebuah program komputer berjalan dalam skala kecil, mungkin hal ini tidak menjadi masalah besar. Tapi jika program komputer tersebut berjalan di skala data dan proses yang besar, kompleksitas algoritme menjadi isu yang cukup penting. Ini artinya, belajar coding saja tidak cukup. Maka dari itu anak diberikan panduan sederhana yang dapat meningkatkan kapasitas berpikir anak, tugas ini diberikan kepada yayasan DigiKids oleh Sekolah Al-Azhar Syifa Budi Solo, bertujuan agar anak berhasil meraih tujuan dari pemikiran komputasional tersebut. 


\section{Limitless Imagination dan Creativity}

Setelah anak dapat melakukan pemecahan masalah yang kompleks dan memiliki pemikiran komputasional, anak dapat menciptakan dan memecahkan masalahnya sendiri hanya dengan membayangkan langkah- langkah pemecahan masalah dan melakukan percobaan dari imajinasi yang dimiliki anak, dari proses-proses ini terbentuk pemikiran yang kreatif terhadap anak.

Anak yang mengikuti ekskul coding memiliki tingkat kecerdasan berpikir logika jauh lebih baik dibandingkan anak yang tidak mengikuti ekskul coding. Anak sekolah dasar yang memiliki imajinasi dan kekereativitas yang lebih baik dan rasa keingin tahuan anak yang sangat tinggi sehingga membuat anak tertarik terhadap coding ini merupakan akar dari meningkatnya kecerdasan berpikir komputasional yang baik.

\section{SIMPULAN}

Dalam kegiatan ekstrakulikuler coding menjadikan siswa dapat memecahkan masalah dengan cara baru karena permaian dalam komputer menggunakan bahasa pemrograman visual yang akan melatih logika dan konsep berfikir siswa sehingga siswa terbiasa untuk memecahkan masalah secara sistematis. Siswa dapat lebih cerdas dalam menggunakan teknologi. Tidak hanya sekedar mengerti cara memainkan aplikasi di ponsel saja tetapi siswapun dapat membuat suatu permainan atau aplikasi sendiri. Mempelajari coding akan mendorong kreativitas siswa karena dengan coding ia dapat membuat suatu permainan sesuai dengan ide yang dimilikinya.

\section{DAFTAR PUSTAKA}

Clements, Douglas H. \& Gullo, Dominic F. . (1984). Effects of Computer Programming on Young Children's Cognition [online]. Ohio: Journal of Educational Psychology. Available from : ResearchGate [accessed 13 February 2020].

Goran, Zaharija, Mladenović, Saša, \& Boljat, Ivica. (2013). Introducing Basic Programming Concept to Elementary School Children [online]. Croatia : Elsevier Ltd. Available from : Science Direct [accessed 14 February 2020].

Kaplancali, Ugur Tevfik, \& Demirkol, Zafer. (2017). Teaching Coding to Children: A Methodology for Kids 5+ [online]. Turkey : Science 
Publishing Group. Available from : ResearchGat [accessed 13 February 2020] .

Mladenović, Monika, Krpan, Divna, \& Mladenović, Saša. (2017). LEARNING PROGRAMMING FROM SCRATCH [online]. Croatia : University of Split, Faculty of Science Croatia. Available from : ResearchGate [accessed 13 February 2020].

Strawhacker, Amanda, \& Bers, Marina Umaschi. (2018). What they learn when they learn coding: investigating cognitive domains and computer programming knowledge in young children [Online]. Massachusetts : Association for Educational Communications and Technology. Available from : ResearchGate [accessed 14 February 2020].

Wibirama, Suna. (2019). Benarkah Belajar Coding Akan Menjadi Solusi Untuk Memajukan Ekonomi Digital? [online]. Yogyakarta: Universitas Gadjah Mada. Available from : Medium [accessed 16 February 2020] 